\title{
Characterization and Land Suitability Evaluation for Cocoyam in Southern Nigeria
}

\author{
M.E. NSOR* \& A.E. AKPAN \\ (M.E.N \& A.E.A.: Department of Soil Science and Meteorology, Michael Okpara \\ University of Agriculture Umudike, Abia State, Nigeria) \\ *Corresponding author's email: michaeledimnsor@gmail.com
}

\begin{abstract}
The soils on diverse landforms in Ikot Esidem, Southern Nigeria were characterized and their suitability evaluated for three varieties of cocoyam. The study area was stratified into flood plains, inland valleys, gentle slopes and crest. The results indicate that sand (30-78\%) dominated pedons of gentle slopes and crest while silt (25-55\%) and clay (19-51\%) dominated the pedons of flood plains and inland valleys. The soils of flood plains and inland valleys were moderately acid (pH 5.0-5.7), medium to high in organic carbon $(6.3-20.5 \mathrm{~g} / \mathrm{kg})$ and medium to high in base saturation (BS) (46-90\%). The gentle slopes and crest units were strongly acid ( $\mathrm{pH}$ 4.0-5.1), low in organic carbon $(4.0-11.3 \mathrm{~g} / \mathrm{kg})$ and base saturation $(20.5-34.7 \%)$. The land suitability evaluated the flood plains and inland valleys as moderately suitable and the gentle slopes and crest as not suitable for Dasheen Type Taro. The flood plains and inland valleys were also evaluated moderately suitable, whereas gentle slopes and crest were marginally suitable for Eddoe Type Taro. Efficient water control drainage and erosion control will enhance cocoyam cultivation depending on terrain type.
\end{abstract}

Keywords: Characterization; Landforms; Suitability; Evaluation; Cocoyam Original scientific paper. Received 20 Jan 2020; revised 15 Feb 2021

\section{Introduction}

Land suitability is the ability of a portion of land to tolerate the production of crops in a sustainable manner. Halder (2013) remarked that soil characterization and suitability evaluation allow the identification of main limiting factors for particular crop production and enables decision makers to develop a crop management system for increasing the land productivity in a sustainable manner. Land suitability is a function of crop requirements and land characteristics. It is a measure of how well the qualities of a land unit matches the requirements of a particular type of land use (FAO, 2007). Okonkwo and Nsor (2015) remarked that soil characterization and fertility evaluation are prelude to sustained crop production.

The evaluation should be periodically carried out to determine its suitability for specific uses and management practices required. The soil information obtained can be used for a more realistic land use recommendation and present its constraints (Nsor et al., 2014). This practice promotes suitable use and proper management of environmental resources.

Ghana Jnl Agric. Sci. 56 (1), $26-47$

GJAS is an Open Access Journal and distributed under the terms of the Creative Commons (CC) License [CC BY 4.0] 
FAO (2009) observed that the present shortage of good land for food production caused by competing demand for other land uses such as industrialization, grazing, fuel wood, cash crops and their degradation, complicated by unsuitable land use practices calls for a reliable land evaluation. A visionary technology hinged on efficient land use, based on suitability recommendation and management will resuscitate our soils for enhance agricultural productivity (Udealor et al., 1996).

\section{Cocoyam (Colocasia spp) is a} herbaceous perennial crop mainly grown for its edible corm and roots. After yam and cassava, cocoyam is considered the third most important tuber crop in Nigeria (Olayiwola et al., 2013). Cocoyam is rich in carbohydrates and is an important food crop. Watanabe (2002) noted that despite its importance as a staple food in many countries; cocoyam is still an insufficiently studied and underutilized crop. Efforts need to be made and measures put in place to popularize, enhance and increase its use as food among the populace through the adaptation of technologies for its processing to increase cocoyam utilization (Adejumo \& Bamidele, 2012).

There is a dearth of soil information in Akwa Ibom State especially on terrain features and soil characteristics, likely to assist farmers in cocoyam production. Most previous soil studies in the study area did not cover most of the cluster villages and besides evaluation of the suitability of these soils on diverse landforms for cocoyam, a major staple food in the state had not been considered. The need to generate soil information on land terrain distribution, soil potentials and constraints for cocoyam production in the study area necessitated this study, with the objective of characterizing and evaluating the suitability of soils on diverse landforms in the study area for cocoyam cultivation.

\section{Materials and Methods}

\section{Study Area}

This study was carried out in Ikot Esidem, Ibiomo Ibom Local Government Area of Akwa Ibom State, located in the humid tropics of the south-southern region of Nigeria. The study area lies between latitudes $05^{\circ} 13^{\prime} 10^{\prime \prime}, 05^{\circ} 17^{\prime}$ $50^{\prime \prime} \mathrm{N}$, and longitudes $07^{\circ} 50^{\prime} 00^{\prime \prime}, 07^{\circ} 5030^{\prime \prime} \mathrm{E}$ (Figure 1).

The climate of the study area is humid tropical, with an annual rainfall of about 2500 to $3000 \mathrm{~mm}$. Mean annual temperature varies between 27 and $28^{\circ} \mathrm{C}$, with relative humidity of 75 to $80 \%$. The dominant parent materials in the study area are sandstones, shale and alluvium. The soil moisture regime ranged from udic in the elevated areas to aquic in the low-lying areas (Usoro \& Akpan, 2010).

\section{Sampling Technique}

The stratified simple random sampling technique based on topographic attributes of the slope was adopted in this study. A reconnaissance survey of the study area was carried out to complement information contained in the GIS acquired topographic map of the area. The study area was stratified on the basis of existing terrain features into flood plains, inland valleys, gentle slopes, and crests respectively. Two profile pits per terrain type were dug. A hand-held global positioning system (GPS) receiver was used to determine the geographical positioning altitude and coordinates of profile pits in the various sampling locations. The different terrain types constituted the various mapping units. 


\section{Field Investigation of Soil Properties}

Soil morphology was described in the field according to the guidelines for soil profile description (FAO, 2006). Core soil samples for bulk and particle density determination were collected at depths $0-25 \mathrm{~cm}$ and $50-75 \mathrm{~cm}$ respectively. Soil samples were also collected from each genetic horizon in all the profile pits for routine physical and chemical laboratory analysis.

\section{Laboratory Analysis}

Soil samples for laboratory analysis were airdried, crushed and sieved through a $2 \mathrm{~mm}$ mesh-sized sieve. Particle size analysis was determined by the Boyoucous hydrometer method (Gee \& Or, 2002). The bulk density was determined by the cylindrical core method. Total porosity was calculated from the values of bulk density using the relationship in equation 1.

$\mathrm{P}=\left(1-\frac{\Delta b}{\Delta p}\right)$

where, $\mathrm{P}=$ porosity, $\Delta \mathrm{b}=$ Bulk Density, $\Delta \mathrm{p}=$ particles density, with an assumed particle density of $2.65 \mathrm{~g} / \mathrm{cm}^{3}$,
Soil $\mathrm{pH}$ was determined using $\mathrm{pH}$ meter in a 1:2.5 soil: water suspension. Organic carbon was determined by the dichromate wet oxidation method of Walkley and Black (Nelson \& Sommers, 1996). Available phosphorus was determined using Bray II method and estimated by the molybdenum blue colour technique (Kuo, 1996). Total nitrogen was determined using micro Kjeldahl method (Bremner, 1996). Exchangeable Acidity $\left(\mathrm{H}^{+}\right.$and $\left.\mathrm{Al}^{3+}\right)$ was determined by titration method from an extract obtained using IN $\mathrm{HCl}$ solution. Cation exchange capacity was determined by the ammonium acetate $\left(\mathrm{NH}_{4} \mathrm{OAc}\right)$ method. Exchangeable $\mathrm{K}$ and $\mathrm{Na}$ in the extract were determined by flame photometry while exchangeable $\mathrm{Ca}$ and $\mathrm{Mg}$ were determined by the EDTA methodology. Available micronutrients ( $\mathrm{Fe}, \mathrm{Zn}, \mathrm{Mn}$ and $\mathrm{Cu}$ ) were extracted with $\mathrm{IN} \mathrm{HCl}$ and determined by Atomic Absorption Spectrophotometry (AAS) using the Association of Analytical Chemist (AOAC) 1990 methodology. 


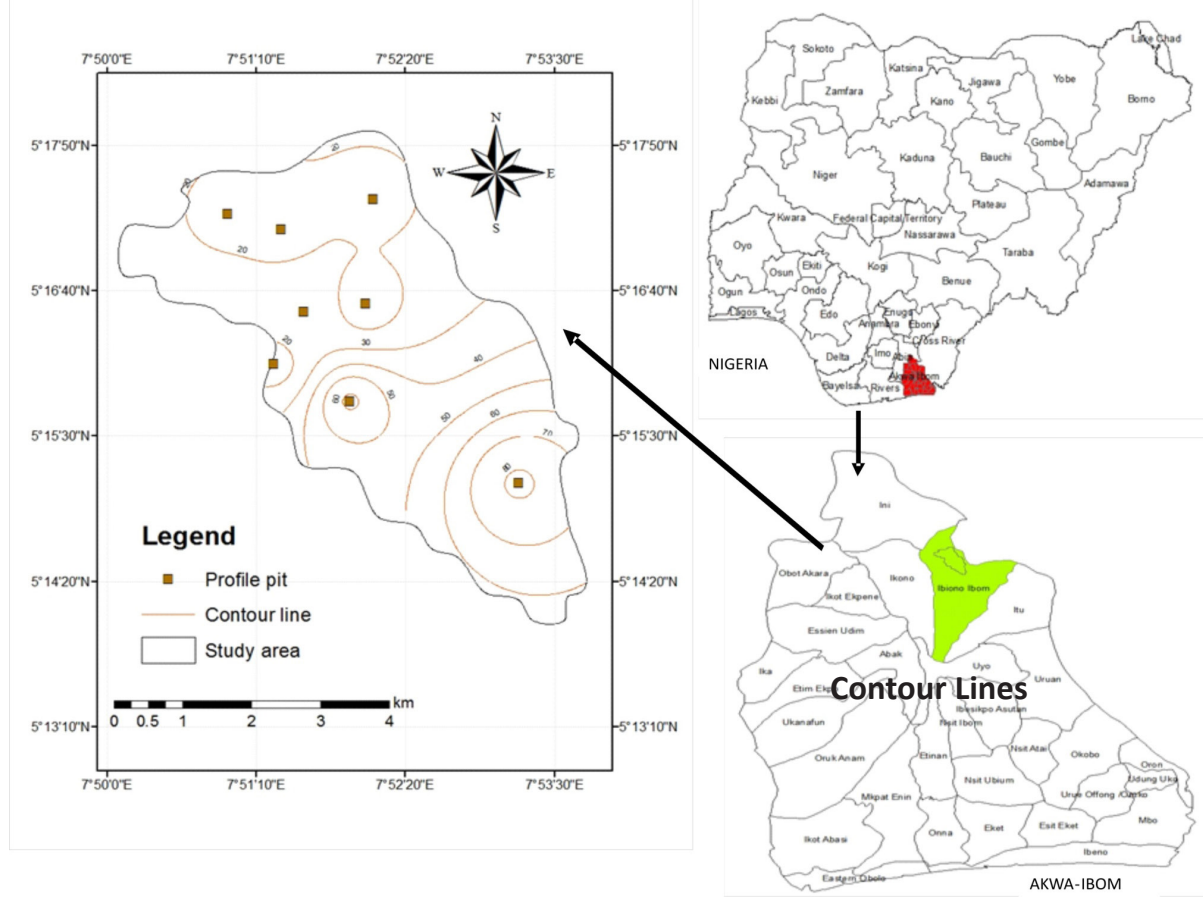

Fig. 1: Topographic map of IkotEsidem,Ibiono, Akwa Ibom State, South Southern, Nigeria

The Parametric Square Root method degrees of limitations. (Khaddir, 1986) was used to calculate the land Percentage Ratings \%: $100|95| 85|60|<40$ productivity index using equation 2 below:

$$
\mathrm{PI}=\mathrm{R} \min \mathrm{X} \sqrt{\frac{A}{100} X \frac{B}{100} X \frac{C}{100} X} \ldots
$$

Where:

$\mathrm{PI}=$ Productivity index $(\%)$

$\mathrm{R}_{\min }=$ factor with minimum rating

$\mathrm{A}, \mathrm{B}, \mathrm{C}$, etc $=$ Ratings of different remaining factors

All the factors of the land characteristic were inserted in the square root, except the factor with the least land characteristic limitation among them. The non-parametric simple limitation method was also employed.

The following percentage ratings according to Riquier et al. (1970) were used for these

Degree of Limitation: None $\mid$ slight $\mid$ moderate | severe | very severe

Based on the resulting productivity index (PI), the soils in the study area were assigned productivity classes as indicated below

Class $1=(65-100 \%$, excellent $)$

Class $2=(35-64 \%$, good $)$

Class $3=(20-34 \%$, Average $)$

Class $4=(8-19 \%$, poor $)$

Class $5=(0-7 \%$, extremely poor $)$

These productivity classes 1-5 are assumed to correspond to the FAO (2006) Land suitability classes of SI (High), S2 (Moderate), S3 (Marginal), N1 (currently not suitable), N2 (Permanently not suitable). The potentials and limitations of land qualities/characteristics in 
determining the suitability of the area for three varieties of cocoyam cultivation (Taro- Eddoe type- Colocasia esculenta var. antiquorum plucknett, Taro- Dasheen type- Colocacia esculenta var. esculenta plucknett, and TanniaXanthosoma sagittfolium) were evaluated using FAO frame work for Land suitability Evaluation (FAO, 2006). The parametric method consists of numerical rating of different limitation levels of land characteristics according to a numerical scale between the maximum and the minimum value.

\section{Results and Discussion}

The data on morphology, physical and chemical characteristics of soils on diverse landforms in Ikot Esidem, Ibiono Ibom L.G.A. of Akwa Ibom State, Nigeria is presented and discussed below.

\section{Morphological Characteristics}

Table 1 presents the morphological characteristics of soils in the study area. The soils of flood plain landform occur on level or nearly level $(0-2 \%)$ physiography. This soil unit occupies an area of about 10.8 ha (14.1\%) of the total study area. Under moist conditions, these soils had brownish-black (5YR 3/1) to brownish-gray (5YR 5/1) surface soils over reddish gray $(2.5 \mathrm{YR} 6 / 1)$ subsurface soil colours (Table 4.1). The brownish-black tinge in the ' $\mathrm{A}$ ' horizon of pedons 1 and 2 representing this landform type was due to the presence of accumulated organic matter which is the main colouring agent of top soils and especially in flood plains (Nsor \& Akamigbo, 2009). The entire pedons of flood plains soil units were also characterized with a few fine faint bright brown (5YR 5/6) to common medium reddish brown (5YR 4/6) mottles. This redoximorphic feature is evident of poor drainage arising from seasonal rise in the water table. This observation corroborates Akamigbo et al. (2002). The soils of this landform type were also characterized by weak fine to medium granular epipedon structural aggregates over moderate to strong, medium to coarse sub-angular blocky endopedon structures. The consistence of this unit indicated soft to slightly hard top soils over hard to very had subsoil (dry); loose to friable top soils over firm to very firm sub-soils (moist); and slightly sticky-slightly plastic top soils over sticky-plastic to very sticky-very plastic sub-soils(wet) Table 1.

The soils of inland valley landform occur on nearly level to gentle slopes (2-4\%) physiography and were represented by pedons 3 and 4. This soil mapping unit is about 38.5 ha $(50.3 \%)$ of total study area. The soils of this landform type had moist soil colour of grayish-brown (5YR 4/2) top soils over brownish grey (5YR 5/1) sub-soil colours (Table 1). The pedons of this soil unit were also mottled throughout the entire soil depth indicating evidence of gleization. This mottling might be due to the oxidation and reduction of iron and or manganese coupled with their removal and translocation as evidence in the reddish oily water flowing on the soil surface. Similar observations were reported by Nsor $e t$ al. (2014) in their study on physico-chemical evaluation and site suitability of soils along River Cross. The inland valley soil unit had weak fine to medium granular top soil structural aggregates over moderate to strong, medium to coarse prismatic sub-soil structures (Table 1). Essoka and Esu (2003) encountered prismatic structures in sub-soils of some inland valleys in central Cross River State, Nigeria. The consistence of the inland valley soils in the study area indicated a soft to slightly hard top soil over hard to very hard sub-soil (dry); very 
friable to friable top soil over firm to very firm sub-soils (moist) and slightly sticky-slightly plastic top soil over sticky-plastic to very sticky-very plastic sub-soil (wet), Table 1.

The soils of gentle slope landforms occur on gently undulating slope (4-7\%) physiography and represented by pedons 5 and 6 occupying an area of about 21.6 ha (28.2\%) of total study area. Under moist conditions, the pedons of this landform type had dark reddishbrown $(5 \mathrm{YR} 3 / 2)$ to bright reddish-brown (5YR 4/6) epipedons over reddish-brown (5YR $4 / 8$ ) to greyish brown (7.5YR 5/2) endopedons. The greyish brown subsoil in pedon 3 might be a result of its shale parent material. The soils had weak fine granular top soils over moderate to strong medium sub-angular blocky subsoil structures. The sub-soil of pedon 3 was characterized by strong medium platy structure which might be due to the influence of shale parent material (Table 1). The consistence of this soil unit revealed a loose to soft top soil over slightly hard to hard sub-soil (dry); very friable to friable top soil over firm sub-soils (moist) and non-stick-non plastic top soil over sticky-plastic sub-soil (wet), Table 1. The sticky-plastic sub-soil is evident of argillic Bt sub soil diagnostic horizon.

The soils on crest land form in the study area had slope in the range of $7-12 \%$ referred to as being very strongly sloping. This soil unit occupies a land area of about 5.7 ha $(7.4 \%)$ of total study area. The soils on this landform had moist soil colours of dark reddish-brown (5YR $3 / 2)$ over bright brown $(2.5 \mathrm{YR} 5 / 8)$ to orange (5YR 6/8). These soils were also characterized by weak fine granular top soil epipedons over moderate to strong sub-angular blocky structures (Table 1). The consistence indicated a soft to slightly hard top soil over hard subsoil (dry); very friable to friable top soil over firm sub-soils (moist) and non-sticky-slightly plastic top soils over slightly sticky-slightly plastic to sticky-plastic sub-soils (wet) Table 1.

TABLE 1

Morphological Characteristics of Soils along a Toposequence at Ikot Esidem, Ibiono Ibom L.G.A, Akwa Ibom State, Nigeria

\begin{tabular}{|c|c|c|c|c|c|c|c|c|c|c|}
\hline \multirow[b]{2}{*}{$\begin{array}{l}\text { Horizon } \\
\text { Designa- } \\
\text { tion }\end{array}$} & \multirow{2}{*}{$\begin{array}{l}\text { Horizon } \\
\text { Thick- } \\
\text { ness } \\
(\mathrm{cm})\end{array}$} & \multirow[b]{2}{*}{ Major colour } & \multirow[b]{2}{*}{ Mottles } & \multicolumn{7}{|c|}{ CONSISTENCE } \\
\hline & & & & Texture & Structure & Dry & Moist & Wet & Roots & Pores \\
\hline \multicolumn{11}{|c|}{ Pedon 1 (Flood plain) 5017'24.7"N; 7052'4.62"E Ele. 13m } \\
\hline Ap & $0-16$ & $5 Y R$ 4/1; Bg & 5YR 5/6 fff, Brb & $\mathrm{SiCL}$ & $\begin{array}{l}\text { 1F gran- } \\
\text { ular }\end{array}$ & $\mathrm{s}$ & I & ss-sp & $\mathrm{cm}$ & $\mathrm{cm}$ \\
\hline $\mathrm{Bgh}_{1}$ & $16-45$ & 5YR 5/1; Bg & $\begin{array}{l}\text { 5YR 5/8 Cmd, } \\
\text { Brb }\end{array}$ & $\mathrm{SiCL}$ & $\begin{array}{l}\text { M gran- } \\
\text { ular }\end{array}$ & sh & $\mathrm{fr}$ & $s-p$ & $\mathrm{ff}$ & $\mathrm{cm}$ \\
\hline $\mathrm{Bgh}_{2}$ & $45-78$ & $5 Y R$ 6/1; Bg & $\begin{array}{l}\text { 5YR 4/6 Cmd, } \\
\text { Rb }\end{array}$ & $\mathrm{CL}$ & $2 \mathrm{M} \mathrm{sbk}$ & $\mathrm{h}$ & f & vs-vp & fvf & mvf \\
\hline $\mathrm{Bgh}_{3}$ & $78-122$ & $5 Y R 6 / 1 ; B g$ & $\begin{array}{l}\text { 5YR 6/8 Mmp, } \\
0\end{array}$ & C & $3 \mathrm{C} \mathrm{sbk}$ & vh & vf & vs-vp & fvf & mvf \\
\hline \multicolumn{11}{|c|}{ Pedon 2 (Flood plain) 5017'9.13"N; 7051'20.89"E Elev. $17 \mathrm{~m}$} \\
\hline Ap & $0-11$ & $5 Y R 3 / 1 ; \mathrm{Bbl}$ & & $\mathrm{SiCl}$ & $\begin{array}{l}1 \mathrm{M} \text { gran- } \\
\text { ular }\end{array}$ & $\mathrm{s}$ & $\mathrm{fr}$ & ss-sp & cf & $\mathrm{CC}$ \\
\hline $\mathrm{Bgh}_{1}$ & $11-29$ & 2.5YR 5/1; Rg & $\begin{array}{l}2.5 Y R 5 / 6 ; \text { fff, } \\
\mathrm{Bb}\end{array}$ & SCL & $2 \mathrm{M} \mathrm{sbk}$ & sh & $\mathrm{fr}$ & s-sp & fvf & ff \\
\hline
\end{tabular}




\begin{tabular}{|c|c|c|c|c|c|c|c|c|c|c|}
\hline $\mathrm{Bgh}_{2}$ & $29-54$ & 2.5YR 6/1; Rg & $\begin{array}{l}2.5 Y R \\
\text { Cff, O }\end{array}$ & $\mathrm{CL}$ & $2 \mathrm{M} \mathrm{sbk}$ & $\mathrm{vh}$ & f & vs-vp & fc & fvf \\
\hline $\mathrm{Bgh}_{3}$ & $54-105$ & 2.5YR 5/1; Rg & $\begin{array}{l}2.5 Y R \quad 5 / 6 ; \\
\text { Cmd, Bb }\end{array}$ & C & $3 \mathrm{M} \mathrm{sbk}$ & eh & vf & vs-vp & fc & cf \\
\hline \multicolumn{11}{|c|}{ Pedon 3 (Inland valley) $5^{\circ} 16^{\prime} 34.96 " \mathrm{~N} ; 7^{\circ} 52^{\prime} 0.56^{\prime \prime} E$ Elev. $14 \mathrm{~m}$} \\
\hline Ap & $0-23$ & $5 Y R 4 / 2 ; G b$ & $5 Y R 4 / 6$ fff; Brb & $\mathrm{SiCL}$ & $\begin{array}{l}\text { 1F gran- } \\
\text { ular }\end{array}$ & s & fr & ss-sp & ff & $\mathrm{mm}$ \\
\hline $\mathrm{Bg}_{1}$ & $23-41$ & 5YR 5/1; Bg & $\begin{array}{l}\text { 5YR } 7 / 3 \text { fmd; } \\
\text { Drb }\end{array}$ & $\mathrm{SiCl}$ & $\begin{array}{l}1 \mathrm{~F} \text { pris- } \\
\text { matic }\end{array}$ & $\mathrm{sh}$ & f & $s-p$ & fvf & cf \\
\hline $\mathrm{Bg}_{2}$ & $41-69$ & 5YR 5/1; Bg & $\begin{array}{l}5 Y R \quad 5 / 6 \quad f f d \\
\text { Brb }\end{array}$ & $\mathrm{CL}$ & $\begin{array}{l}2 \mathrm{M} \text { pris- } \\
\text { matic }\end{array}$ & $\mathrm{h}$ & vf & $s-p$ & fvf & mvf \\
\hline $\mathrm{Bg}_{3}$ & $69-130$ & 5YR 5/1; Bg & $\begin{array}{l}5 Y R \quad 5 / 6 \text { fmd; } \\
\text { Brb }\end{array}$ & $\mathrm{CL}$ & $\begin{array}{l}3 \mathrm{M} \text { pris- } \\
\text { matic }\end{array}$ & $\mathrm{vh}$ & vf & vs-vp & fvf & mvf \\
\hline \multicolumn{11}{|c|}{ Pedons 4 (Inland valley) 5016'4.7"N; 7051'18.14"E Elev. 21} \\
\hline Ap & $0-22$ & $5 Y R$ 4/2; Gb & 5YR 5/6 fff; Brb & SiL & $\begin{array}{l}1 \mathrm{M} \text { gran- } \\
\text { ular }\end{array}$ & $\mathrm{s}$ & vfr & ss-sp & $\mathrm{CC}$ & $\mathrm{cm}$ \\
\hline $\mathrm{Bg}_{1}$ & $22-47$ & 5YR 5/1; Bg & 5YR 5/8 fff; Brb & SiL & $\begin{array}{l}2 \mathrm{Mpris-} \\
\text { matic }\end{array}$ & sh & fr & $s-p$ & $\mathrm{fm}$ & $\mathrm{cm}$ \\
\hline $\mathrm{Bg}_{2}$ & $47-69$ & 5YR 5/1; Bg & $5 Y R 6 / 8$ fmd; 0 & C & $\begin{array}{l}2 \mathrm{M} \text { pris- } \\
\text { matic }\end{array}$ & $\mathrm{h}$ & f & s-vp & ff & $\mathrm{mf}$ \\
\hline $\mathrm{Bg}_{3}$ & $69-110$ & 5YR 5/1; Bg & $\begin{array}{l}\text { 5YR 5/8 Cmd; } \\
\text { Brb }\end{array}$ & C & $\begin{array}{l}3 \mathrm{C} \text { pris- } \\
\text { matic }\end{array}$ & vf & vh & vs-vp & ff & mvf \\
\hline \multicolumn{11}{|c|}{ Pedon 5 (Gentle slope) 5017'17.77"N; 7050'56.14"E Elev. 19m } \\
\hline Ap & $0-13$ & 5YR 4/6; Brb & & SL & $\begin{array}{l}\text { 1F gran- } \\
\text { ular }\end{array}$ & I & vfr & ns-np & ff & $\mathrm{cc}$ \\
\hline Bt & $13-36$ & 5YR 5/8; Brb & & $\mathrm{CL}$ & $2 \mathrm{M} \mathrm{sbk}$ & $\mathrm{s}$ & fr & ss-sp & $\mathrm{fm}$ & $\mathrm{cm}$ \\
\hline Btv $_{1}$ & $36-72$ & $5 Y R 4 / 8 ; \mathrm{Rb}$ & & $\mathrm{SC}$ & $2 \mathrm{M} \mathrm{sbk}$ & $\mathrm{h}$ & f & $s-p$ & fvf & cf \\
\hline $\mathrm{Btv}_{2}$ & $72-125$ & $5 Y R 5 / 2 ; G b$ & & C & 3M platy & $\mathrm{h}$ & f & $s-p$ & $\mathrm{fm}$ & mvf \\
\hline \multicolumn{11}{|c|}{ Pedon 6 (Gentle slope) 5016'30.63"N; 7051'31.5"E Elev. 26m } \\
\hline Ap & $0-10$ & $5 Y R 3 / 2 ;$ Drb & & LS & $\begin{array}{l}\text { 1F gran- } \\
\text { ular }\end{array}$ & $\mathrm{s}$ & vfr & ns-np & $\mathrm{fm}$ & $\mathrm{mm}$ \\
\hline $\mathrm{Bt}_{1}$ & $10-29$ & $5 Y R$ 4/8; Rb & & $\mathrm{SCL}$ & $1 \mathrm{~F} \mathrm{sbk}$ & sh & fr & s-p & ff & $\mathrm{mm}$ \\
\hline $\mathrm{Bt}_{2}$ & $29-43$ & $5 Y R$ 4/8; Rb & & SC & $1 \mathrm{M} \mathrm{sbk}$ & sh & f & $s-p$ & fvf & $\mathrm{cm}$ \\
\hline $\mathrm{Bt}_{3}$ & $43-94$ & 5YR 5/8; Brb & & $C$ & $2 \mathrm{M} \mathrm{sbk}$ & $\mathrm{h}$ & $f$ & $s-p$ & fvf & cf \\
\hline \multicolumn{11}{|c|}{ Pedon 7 (Crest) 5015'47.42"N; 7051'52.31"E Elev. 67m } \\
\hline Ap & $0-10$ & $5 Y R$ 3/2; Drb & & SL & $\begin{array}{l}\text { 1F gran- } \\
\text { ular }\end{array}$ & $s$ & vfr & ns-np & $\mathrm{fm}$ & $\mathrm{cm}$ \\
\hline$A B$ & $10-41$ & 5YR 4/4; Drb & & $\mathrm{SCL}$ & $2 \mathrm{M} \mathrm{sbk}$ & sh & $\mathrm{fr}$ & ns-np & $\mathrm{fm}$ & cf \\
\hline $\mathrm{Bt}$ & $41-63$ & 5YR 4/4; Drb & & $\mathrm{SCL}$ & $3 \mathrm{M} \mathrm{sbk}$ & $\mathrm{h}$ & $f$ & ss-sp & ff & $\mathrm{cm}$ \\
\hline$B C$ & $63-95$ & $5 Y R$ 6/3; Db & & SC & 2M platy & $\mathrm{h}$ & $f$ & $s-p$ & fvf & mvf \\
\hline \multicolumn{11}{|c|}{ Pedon 8 (Crest) 5015'8.15"N; 7053'12.44"E Elev. 81m } \\
\hline A & $0-19$ & 5YR 5/6; Brb & & SL & $\begin{array}{l}\text { 1F gran- } \\
\text { ular }\end{array}$ & $\mathrm{s}$ & $\mathrm{fr}$ & ns-np & $\mathrm{cm}$ & $\mathrm{mm}$ \\
\hline$A B$ & $19-44$ & 5YR 6/8; 0 & & SL & $2 \mathrm{M} \mathrm{sbk}$ & $\mathrm{h}$ & f & ss-sp & $\mathrm{fm}$ & $\mathrm{mm}$ \\
\hline $\mathrm{BC}$ & $44-84$ & 2.5YR 5/8; Bb & & $\mathrm{SCL}$ & $3 \mathrm{M} \mathrm{sbk}$ & $\mathrm{h}$ & $f$ & $s-p$ & fvf & $\mathrm{cf}$ \\
\hline
\end{tabular}

Key:

1. Colour: $\mathrm{Brb}=$ Bright reddish brown, $\mathrm{Gb}=$ Greyish Brown, $\mathrm{Drb}=$ Dark reddish brown, $\mathrm{Rb}=\mathrm{Reddish}$ brown, $\mathrm{Drb}=$ Dull reddish brown, $\mathrm{Db}=$ Dull brown, $\mathrm{O}=$ Orange, $\mathrm{Bb}=$ Bright brown, $\mathrm{Bg}=$ Brownish gray, $\mathrm{Bbl}=$ Brownish black, $\mathrm{Rg}=$ Reddish grey

2. Mottles: $\mathrm{fff}=$ few fine faint, $\mathrm{cmd}=$ common medium distinct, $\mathrm{mmp}=$ many medium prominent, $\mathrm{cff}=\mathrm{common}$ fine faint, $\mathrm{mmd}=$ many medium distinct, $\mathrm{mcp}=$ many coarse prominent, $\mathrm{ffd}=$ few fine distinct, fmd = few medium distinct 
3. Structure: $1=$ weak, $2=$ moderate, $3=$ strong, $\mathrm{sbk}=$ sub angular blocky, $\mathrm{f}=$ fine, $\mathrm{m}=$ medium, $\mathrm{c}=\mathrm{coarse}$

4. Texture: $\mathrm{SiCL}=$ Silt clay loam, $\mathrm{CL}=$ Clay loam, $\mathrm{C}=$ Clay, $\mathrm{SL}=$ Sandy loam, $\mathrm{LS}=$ Loamy sand, $\mathrm{SCL}=\mathrm{Sandy}$ clay loam, $\mathrm{SC}=$ Sandy clay, $\mathrm{SiL}=$ Silt loam

5. Consistence: $\mathrm{s}=\mathrm{Soft}, \mathrm{sh}=$ slightly hard, $\mathrm{h}=$ hard, $\mathrm{vh}=$ very hard, $\mathrm{eh}=$ extremely hard, $\mathrm{fr}=\mathrm{friable}, \mathrm{f}=\mathrm{firm}, \mathrm{vf}=$ very firm, vfr = very friable, $1=$ loose, $s s=$ slightly sticky, $s p=$ slightly plastic, $s=$ sticky, vs $=$ very sticky, $v p=$ very plastic, $\mathrm{p}=$ plastic, $\mathrm{np}=$ non plastic, $\mathrm{ns}=$ non-sticky.

6. Pores/Roots: $\mathrm{ff}=$ few fine, $\mathrm{cc}=$ common coarse, $\mathrm{fm}=$ few medium, $\mathrm{cm}=$ common medium, fvf $=$ few very fine, $\mathrm{cf}$ $=$ common fine, $\mathrm{mvf}=$ many very fine, $\mathrm{mm}=$ many medium, $\mathrm{fc}=$ few coarse, $\mathrm{mf}=$ many fine

\section{Physical Characteristics}

Table 2 presents the physical characteristics of soils in the study area. The particle size distribution data showed that sand (30-78\%) dominated pedons of gentle slopes and crest landforms and this decreased with depth (Table 2). Silt (25-55\%) and clay (19-51\%) separates dominated the pedons of flood plains and inland valley landforms. Clay content generally increased with soil depth indicating evidence of argillic (Bt) sub-soil horizons especially in gentle slope and crest landforms. There was no definite sequence in the distribution of silt within the pedons studied. The silt:clay ratios were generally low to moderate $(0.18-2.89 \%)$ for all the pedons studied. The silt:clay ratio was used by Van Wambeke (1962) to differentiate old from young parent materials, and when this ratio was applied here, it could be seen that the gentle slope and crest pedons with lower ratios are in an advanced stage of development while flood plain and inland valley pedons are in their juvenile or immature stages (Abate et al., 2014).

From the data in Table 2 regarding the irregular distribution of silt contents especially in flood plains and inland valleys, it could be concluded that the soils here are actively and continuously receiving substantial amounts of erosional sediments from adjoining high elevation landforms. The soils of flood plain landforms were generally characterized by silty loam top soils over clay loam to clay subsoils. The inland valley soils had silty loam top soils over clay loam to clay sub-soils. The soils of gentle slopes had sandy loam to loamy sand top soils over sandy clay to clayey sub-soils. The soils on crest landforms were characterized with sandy loam top soils over sandy clay loam sub-soil pedons (Table 2). This confirms the existence of both clay migration and translocation in pedons.

Mean bulk density values of $1.07 \mathrm{~g} / \mathrm{cm}^{3}$ for top soils over $1.48 \mathrm{~g} / \mathrm{cm}^{3}$ sub-soils were obtained for soils of flood plains, $1.20 \mathrm{~g} / \mathrm{cm}^{3}$ over $1.45 \mathrm{~g} / \mathrm{cm}^{3}$ for soils of inland valleys, $1.52 \mathrm{~g} / \mathrm{cm}^{3}$ over $1.56 \mathrm{~g} / \mathrm{cm}^{3}$ for soils of crest landforms. The bulk density values in the range $\left(1.01-1.60 \mathrm{~g} / \mathrm{cm}^{3}\right)$ encountered in the study area are ideal for agronomic activities due to the absence of excessively high bulk densities as soils with bulk densities less than $1.65 \mathrm{~g} / \mathrm{cm}$ do not impede root penetration and development (Asadu et al., 1990). The porosities values (34.0-61.9\%) in the study area were directly proportional to percentage sand content and inversely proportional to clay contents. Porosity in the soils of flood plains and inland valley decreased with soil depth with top soils being more porous than sub-soils. This explains why soils of flood plains and inland valley landforms are waterlogged.

Soil erodibility index values were generally in the range $0.96-2.33$ with top soils having higher values than the sub-soils (Table 2). This reflects the vulnerability of top soils to erosive forces of rainfall and wind than the sub-soils. 
TABLE 2

Physical characteristics of Soils in the Study Area

\begin{tabular}{|c|c|c|c|c|c|c|c|c|c|c|}
\hline $\begin{array}{l}\text { Land- } \\
\text { form } \\
\text { Type }\end{array}$ & $\begin{array}{l}\text { Horizon } \\
\text { designa- } \\
\text { tion }\end{array}$ & $\begin{array}{l}\text { Depth } \\
\text { (cm) }\end{array}$ & $\begin{array}{l}\text { Sand } \\
\%\end{array}$ & $\begin{array}{l}\text { Silt } \\
\%\end{array}$ & $\begin{array}{l}\text { Clay } \\
\%\end{array}$ & $\begin{array}{l}\text { Silt: } \\
\text { clay } \\
\text { ratio }\end{array}$ & $\begin{array}{l}\text { Tex- } \\
\text { tural } \\
\text { class }\end{array}$ & $\begin{array}{l}\text { Density } \\
\text { bulkg/ } \\
\text { cm }^{3} \\
\end{array}$ & Porosity & $\begin{array}{l}\text { Soil erodibility } \\
\text { index }\end{array}$ \\
\hline \multirow{8}{*}{ FP } & Ap & $0-16$ & 23 & 48 & 29 & 1.85 & $\mathrm{SiCL}$ & 1.01 & 61.9 & 2.45 \\
\hline & $\mathrm{Bgh}_{1}$ & $16-45$ & 19 & 46 & 35 & 1.31 & SiCL & & & 1.86 \\
\hline & $\mathrm{Bgh}_{2}$ & $45-78$ & 35 & 32 & 33 & 0.97 & $\mathrm{CL}$ & 1.50 & 43.4 & 2.03 \\
\hline & $\mathrm{Bgh}_{3}$ & $78-122$ & 25 & 25 & 50 & 0.50 & $\mathrm{C}$ & & & 1.00 \\
\hline & Ap & $0-11$ & 25 & 42 & 33 & 1.27 & $\mathrm{SiCL}$ & 1.12 & 57.7 & 2.03 \\
\hline & $\mathrm{Bgh}_{1}$ & $11-29$ & 22 & 42 & 36 & 1.17 & $\mathrm{CL}$ & & & 1.78 \\
\hline & $\mathrm{Bgh}_{2}$ & $29-54$ & 35 & 25 & 40 & 0.63 & CL & 1.45 & 45.3 & 1.50 \\
\hline & $\mathrm{Bgh}_{3}$ & $54-105$ & 25 & 30 & 45 & 0.67 & $\mathrm{C}$ & & & 1.22 \\
\hline \multirow{9}{*}{ IV } & Ap & $0-23$ & 26 & 55 & 19 & 2.89 & $\mathrm{SiL}$ & 1.17 & 55.8 & 4.26 \\
\hline & $\mathrm{Bg}_{1}$ & $23-41$ & 22 & 49 & 29 & 1.69 & $\mathrm{SiCL}$ & & & 2.45 \\
\hline & $\mathrm{Bg}_{2}$ & $41-69$ & 29 & 36 & 35 & 1.03 & CL & 1.54 & 41.9 & 1.78 \\
\hline & $\mathrm{Bg}_{3}$ & $69-130$ & 28 & 36 & 36 & 1.00 & $\mathrm{CL}$ & & & 1.78 \\
\hline & Ap & $0-22$ & 29 & 25 & 46 & 0.54 & $\mathrm{SiL}$ & 1.22 & 54.0 & 1.17 \\
\hline & $\mathrm{Bg}_{1}$ & $22-47$ & 25 & 45 & 30 & 1.50 & $\mathrm{SiL}$ & & & 2.33 \\
\hline & $\mathrm{Bg}_{2}$ & $47-64$ & 20 & 40 & 40 & 1.00 & $\mathrm{C}$ & 1.35 & 49.1 & 1.50 \\
\hline & $\mathrm{Bg}_{3}$ & $64-110$ & 20 & 38 & 42 & 0.90 & $\mathrm{C}$ & & & 1.38 \\
\hline & Ap & $0-13$ & 70 & 16 & 14 & 1.14 & SL & 1.39 & 47.5 & 6.14 \\
\hline \multirow{7}{*}{ GS } & $\mathrm{Bt}$ & $13-36$ & 49 & 21 & 30 & 0.70 & $\mathrm{CL}$ & & & 2.33 \\
\hline & $\mathrm{Btv}_{1}$ & $36-72$ & 47 & 8 & 45 & 0.18 & $\mathrm{SC}$ & 1.45 & 45.3 & 1.22 \\
\hline & $\mathrm{Btv}_{2}$ & $72-125$ & 30 & 19 & 51 & 0.37 & $\mathrm{C}$ & & & 0.96 \\
\hline & $\mathrm{Ap}$ & $0-10$ & 78 & 10 & 12 & 0.83 & LS & 1.64 & 38.1 & 7.33 \\
\hline & $\mathrm{Bt}_{1}$ & $10-29$ & 62 & 11 & 27 & 0.41 & SCL & & & 2.70 \\
\hline & $\mathrm{Bt}_{2}$ & $29-43$ & 49 & 15 & 36 & 0.42 & $\mathrm{SC}$ & 1.67 & 37.0 & 1.78 \\
\hline & $\mathrm{Bt}_{3}$ & $43-94$ & 31 & 24 & 45 & 0.53 & $\mathrm{C}$ & & & 1.22 \\
\hline \multirow{7}{*}{ CR } & Ap & $0-10$ & 65 & 16 & 19 & 0.84 & SL & 1.29 & 51.3 & 4.26 \\
\hline & $\mathrm{AB}$ & $10-41$ & 63 & 14 & 23 & 0.61 & SCL & & & 3.34 \\
\hline & $\mathrm{Bt}$ & $41-63$ & 49 & 17 & 34 & 0.50 & SCL & 1.50 & 43.4 & 1.94 \\
\hline & $\mathrm{BC}$ & $63-95$ & 48 & 15 & 37 & 0.41 & $\mathrm{SC}$ & & & 1.70 \\
\hline & A & $0-19$ & 75 & 9 & 16 & 0.56 & SL & 1.47 & 44.5 & 5.25 \\
\hline & $\mathrm{AB}$ & $19-44$ & 69 & 13 & 18 & 0.72 & SL & & & 4.56 \\
\hline & $\mathrm{BC}$ & $44-84$ & 65 & 13 & 22 & 0.59 & SCL & 1.75 & 34.0 & 3.55 \\
\hline
\end{tabular}

Key: $\mathrm{FP}=$ Flood plain, $\mathrm{IV}=$ Inland valley, $\mathrm{GS}=$ Gentle slope, $\mathrm{CR}=$ Crest, $\mathrm{SiCL}=$ Silty clay loam, $\mathrm{CL}=\mathrm{Clay}$ loam, $\mathrm{C}=$ Clay, $\mathrm{SiL}=$ Silty loam, $\mathrm{SL}=$ Sandy loam, $\mathrm{SC}=$ Sandy clay, $\mathrm{LS}=$ Loamy sand, $\mathrm{SCL}=$ Sandy clay loam

Chemical Characteristics

The soils of flood plain landforms were moderately acid $(\mathrm{pH}$ 5.0-5.7) in reaction. This might be due to its alluvial origin which according to Brady and Weil (2008) results in soils high in organic matter which acts as a buffering agent in soils. The moderate acidity implies that essential nutrients are likely to be available for crop uptake. Odunze (2006) asserted that the $\mathrm{pH}$ range of 5.5-6.5 
is optimum for the release of plant nutrients. Organic carbon in the flood plain soils was medium to high $(6.30-20.50 \mathrm{~g} / \mathrm{kg})$. High organic carbon content in the poorly drained soils of flood plain landform may be attributed to waterlogging condition which causes a relative accumulation of organic matter due to reduced microbial activities, less frequent and less severe translocation of mineralized products at the start of the rains and anaerobic decomposition resulting in the release of greenhouse gases associated with waterlogging sites coupled with erosion from the uplands.

Nsor and Akamigbo (2009) also reported high organic matter content for flood plain soils of Central Cross River State, Nigeria. Organic matter content is the most important property in sustainable soil productivity. The mean total nitrogen values of this landform type were $3.75 \mathrm{~g} / \mathrm{kg}$ (Table 3 ). This value was considered high. The high total nitrogen value of this soil unit might be due to high organic matter deposition and little or no leaching losses attributable to the clayey nature of the soils. Idoga et al. (2005) also reported high total nitrogen values for soils of Aliade plains of Benue State, high in clay content. Available phosphorus in the flood plains landforms in the study area was in the range $5.20-11.20 \mathrm{mg} /$ $\mathrm{kg}$, considered low to medium. Phosphorus is the second most critical element influencing plant growth and crop production. Phosphorus level in this soil unit is ideal especially for heavy P feeders such as cocoyam and maize. Amongst the exchangeable cations, calcium was medium $(1.20-3.20 \mathrm{cmol} / \mathrm{kg})$, magnesium was high $(0.67-2.40 \mathrm{cmol} / \mathrm{kg})$, potassium was medium $(0.14-0.30 \mathrm{cmol} / \mathrm{kg})$ and sodium was medium $(0.16-0.37 \mathrm{cmolkg})$, Table 2 . The medium to high levels of exchangeable cations of this landform type might be attributed to its alluvium origin which seasonally enriches these soils with organic debris and erosional sediments. Ahukaemere et al. (2016) also reported high exchangeable cations except for sodium in rice producing soils of Abia State in South Eastern Nigeria. The cation exchange capacity (CEC) in the flood plains by $\mathrm{NH}_{4} \mathrm{OAc}$ was low to medium $(3.50-7.90$ $\mathrm{cmol} / \mathrm{kg}$ ). This value falls within the range of medium fertility according to FMANR (1990). The analysis of micronutrients for flood plains landform type in the study area indicated adequate levels of manganese $(0.67-4.20 \mathrm{mg} /$ $\mathrm{kg}$ ), zinc $(1.32-2.40 \mathrm{mg} / \mathrm{kg})$ and iron $(1.52-$ $7.50 \mathrm{mg} / \mathrm{kg})$. However, the flood plains had marginal level of copper $(0.32-2.95 \mathrm{mg} / \mathrm{kg})$. Generally, these micronutrient levels are ideal for cocoyam, swamp rice, sugar cane and dry season vegetable cultivation in the study area. 
TABLE 3

Chemical Characteristics of Soils in the Study Area

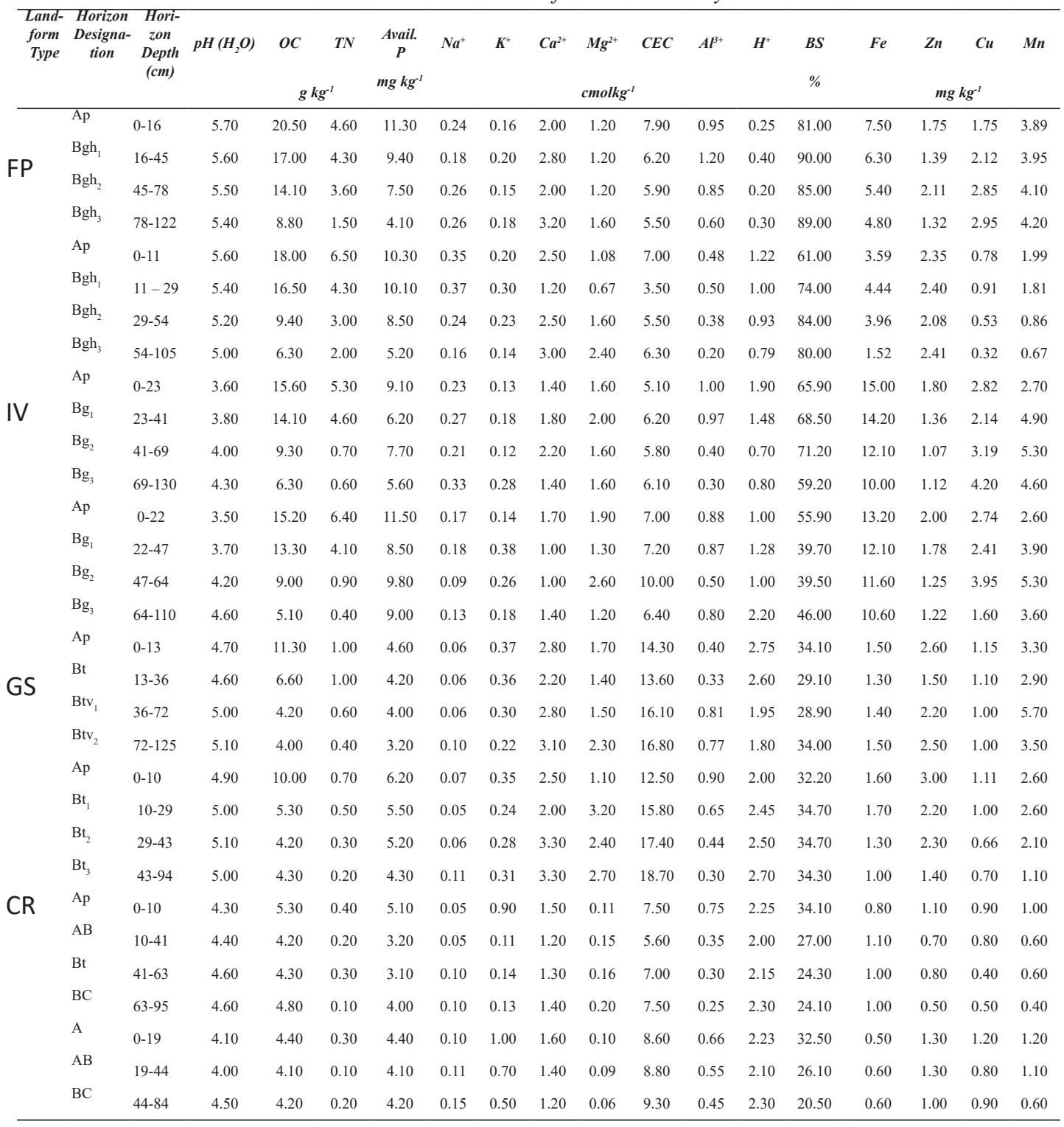


The soils of inland valley landform in the study area had moderate acidity ( $\mathrm{pH}$ 5.1-5.5). This might be due to seasonal enrichments from surrounding uplands of erosion sediments and organic matter. Higher $\mathrm{pH}$ in the top soil of this unit may also be attributed to the influence of organic matter through biogenetic cycling of bases and capillary rise in water within the basin. This process according to Mohammad (2011) reduces the acidification of soils. Organic carbon for inland valley landform was medium (5.10-15.60 g/kg), Table 3. The high organic carbon of this soil unit might be due to increasing deposition and mineralization of organic debris. This agrees with the findings of Nsor et al. (2014). Total nitrogen values were medium to high $(0.40-6.40 \mathrm{~g} / \mathrm{kg})$. This medium to high level of nitrogen may be due to high organic matter content and low leaching losses due to its clayey soil textures. Available phosphorus level $(6.20-11.50 \mathrm{mg} / \mathrm{kg}$ ) in the inland valley landform was considered low to medium. Akamigbo et al. (2002) also reported low to medium levels of total nitrogen and available phosphorus in some fadama soils of Bauchi State, Nigeria. Amongst the exchangeable cations, low to medium levels of calcium $(1.00-2.20 \mathrm{cmol} / \mathrm{kg})$, and magnesium $(1.20-2.60 \mathrm{cmol} / \mathrm{kg})$ were observed. Potassium $(0.13-0.38 \mathrm{cmol} / \mathrm{kg})$ was medium to high (Table 3). The cation exchange capacity for the inland valley landform was in the range $5.10-10.00 \mathrm{cmol} / \mathrm{kg}$ and was rated medium. The implication here is that these inland soils have moderate nutrient holding and supplying capacity. These values are comparable to values obtained by Nsor et al. (2014) for some selected inland valley soils of Central Cross River State. The analysis of available micronutrient indicated toxic levels of iron $(10.00-15.00 \mathrm{mg} / \mathrm{kg})$, and adequate levels of zinc $(1.07-2.00 \mathrm{mg} / \mathrm{kg}), \mathrm{Cu}(1.60-4.20 \mathrm{mg} /$ $\mathrm{kg}$ ) and $\mathrm{Mn}(2.60-5.30 \mathrm{mg} / \mathrm{kg})$, Table 3. These values of micronutrients except iron are ideal for agronomic activities (McKenzie, 1992).

The soils of gentle slope landforms were strongly acid ( $\mathrm{pH} 4.60-5.10)$ in reaction (Table 3). This might be due to intense leaching of basic cations enabled by the coarsetextured nature of these soils and high rainfall experienced in this area. Low organic carbon $(4.0-11.30 \mathrm{~g} / \mathrm{kg})$ was observed in soils of the gentle slopes. The low organic carbon values in this soil unit might be due to low organic debris deposition, high temperatures rainfall and relative humidity (Usoro \& Akpan, 2010), which favours its rapid mineralization and loss. Soil organic matter has been reported to have significant positive influence on the CEC, base saturation, structure, $\mathrm{pH}$, buffering capacity, soil colour and water holding capacity of soils (Afu et al., 2016; \& Nsor et al., 2014). The soils on gentle slopes had low total nitrogen $(0.20-1.00 \mathrm{~g} / \mathrm{kg})$ values. The low nitrogen level is however suggestive of high nitrogen losses as a result of leaching of nitrates as well as crop removal. It was also associated with rapid mineralization of organic matter under an isohyperthermic soil temperature regime and a udic soil moisture regime. Available phosphorus values $(4.00-6.20 \mathrm{mg} / \mathrm{kg}$ ) were generally low in this landform type. This reflects the generally low phosphates reserves of many Nigerian soils, resulting partly from the low content of phosphate in sandstone and shale parent rocks of these soils (Best, 1982), but complicated by high phosphate fixing capacity of the soils (Aluko et al., 2016). Amongst the exchangeable cations, calcium $(2.20-3.30 \mathrm{cmol} / \mathrm{kg})$, magnesium $(1.10-3.20$ $\mathrm{cmol} / \mathrm{kg})$ and potassium $(0.22-0.37 \mathrm{cmol} /$ $\mathrm{kg}$ ) were low to medium. The low to medium 
levels of exchangeable bases in the soils of gentle slope landforms in the study area may be due to the dominance of shale over sandstone parent material (Best, 1982), good crop residue management, and gentle slope terrain characteristics which allows appreciable accumulation and mineralization of organic matter. Cation exchange capacity in this soil unit was high (12.50-18.70 cmol/ $\mathrm{kg})$, implying that the soils had a good nutrient reserve capacity. Available data on micronutrients indicated adequate levels of $\mathrm{Fe}(1.00-1.70$ $\mathrm{mg} / \mathrm{kg}) . \mathrm{Zn}(1.40-3.00 \mathrm{mg} / \mathrm{kg})$ and $\mathrm{Mn}(1.10-$ $5.70 \mathrm{mg} / \mathrm{kg})$. Copper $(0.66-1.15 \mathrm{mg} / \mathrm{kg})$ was deficient in this soil unit.

The soils of crest landforms in the study area were strongly acid $(\mathrm{pH} 4.0-4.60)$. This might be due to rapid removal of organic matter by erosion accelerated by its steep slope $(7-12 \%)$ factor as well as enhanced leaching losses of basic cation due to intense rainfall in the study area. This observation corroborates Nsor and Adesemuyi (2016) who also encountered strong acid conditions in crest topographic positions in their characterization of a toposequence at Ishiagu, Eastern Nigeria. Organic carbon in the crest landform type in the study area was low $(4.10-5.30 \mathrm{~g} / \mathrm{kg})$, Table 3. The low level of organic carbon could be attributed to rapid top soil removal which prevents build-up of organic matter due to slope factors (Sharu et al., 2013). Total nitrogen content was also rated low (0.10-0.40 $\mathrm{g} / \mathrm{kg}$ ). Available phosphorus content of the crest landform type was generally low (3.10-5.10 $\mathrm{mg} / \mathrm{kg}$ ), Table 3 . This reflects the generally low phosphorus reserves of most Nigerian soils, resulting partly from the sandstone parent rocks poor in phosphates (Best, 1982) and also from low organic matter content of this landform type (Sharu et al., 2013).
Amongst the exchangeable cations, calcium $(1.20-1.60 \mathrm{cmol} / \mathrm{kg})$ and magnesium $(0.06-0.20 \mathrm{cmol} / \mathrm{kg})$ were low. Exchangeable potassium was low to medium (1.00-0.90 $\mathrm{cmol} / \mathrm{kg}$ ). Cation exchange capacity values by $\mathrm{NH}_{4} \mathrm{OAc}$ method were low to medium (5.60$9.30 \mathrm{cmol} / \mathrm{kg}$ ), Table 3 . The low organic matter in the crest landform may have influenced and contributed to the low to medium CEC in this soil unit. Afu et al. (2016) also observed that organic matter had a greater effect on CEC than clay colloids, in tropical soils. The study indicated deficient to marginal levels of $\mathrm{Fe}$ $(0.50-1.10 \mathrm{mg} / \mathrm{kg}), \mathrm{Zn}(0.50-1.30 \mathrm{mg} / \mathrm{kg}), \mathrm{Cu}$ $(0.40-1.20 \mathrm{mg} / \mathrm{kg})$ and $\mathrm{Mn}(0.60-1.20 \mathrm{mg} / \mathrm{kg})$, in this landform type.

Suitability Evaluation of Soils in the Study Area The suitability evaluation of soils in the study area was obtained by matching the land characteristics studied with agronomic requirements of three varieties of cocoyam and maize. This was achieved by using the guidelines suggested by Khiddir, (1986) and Sys et al. (1993) for land evaluation and ideal agronomic requirements for three varieties of cocoyam (Sarem et al., 2008; \& Chukwu et al., 2014). The suitability evaluation methods used were the non-parametric (Simple Limitation Method) and the parametric (Square root method).

\section{Suitability Evaluation for Dasheen Type Taro} (Colocasia esculenta var. Esculenta plucknett) NCE 006

The results showed that when climatic requirements (rainfall and temperature) of the study area are matched with the land quality, annual rainfall and temperature scored 95\% (S1) and 85\% (S2) respectively for Dasheen Type Taro cultivation, implying optimatic 
climatic conditions. Topography and drainage conditions were ideal in flood plains and inland valley landforms scoring between 95 (S1) and 85 (S2), Table 5.

Topography (slope) and drainage were marginally suitable (S3) or not suitable (N1) for the gentle slopes and crest landforms in the study area. Amongst the soil characteristics investigated soil texture and structure were moderately suitable (S2) in the flood plains and inland valleys but marginally suitable (S3) in gentle slopes and crest landforms. Soil depth was optimal for all the landform types scoring $95 \%$ (S1). Water table depth was highly suitable (S1) at the flood plains and in inland valleys but not suitable (N1) on gentle slopes and crest landforms (Table 5). Data on chemical characteristics $(\mathrm{pH}$, total nitrogen, organic carbon, exchangeable $\mathrm{K}$ and base saturation) were rated highly to moderately suitable, scoring $95 \%(\mathrm{~S} 1)$ to $85 \%$ (S2) for all landform types for Dasheen type taro cultivation in the study area. Available phosphorus was moderately suitable (S2) at the flood plains and inland valleys but marginally (S3) on gentle slopes and crest landforms.

Aggregate suitability land evaluation by limitation non-parametric method indicated that the soils of flood plains and inland valleys were moderately suitable (S2) while the soils on gentle slopes and crest landforms were currently not suitable (N1) on account of drainage, slope and deep-water table level for Dasheen type taro cultivation. Suitability evaluation by the paramedic square root methods indicated that the soils of flood plains and inland valleys were moderately suitable (S2) while the soils on gentle slopes and crest were not suitable (N1 and N2) Figure 2. 
TABLE 4

Land Quality Rating for Sustainable Production of Three Varieties of Cocoyam (Colocasia spp)

\begin{tabular}{|c|c|c|c|c|c|c|}
\hline Land qualities & Land Characteristics & $\begin{array}{l}\text { Cocoyam } \\
\text { variety }\end{array}$ & High $(>95 \%)$ & $\begin{array}{l}\text { Moderate } \\
(85 \%)\end{array}$ & Severe (60\%) & $\begin{array}{l}\text { Very severe } \\
(<40 \%)\end{array}$ \\
\hline \multicolumn{7}{|l|}{ Climate $(\mathrm{C}):$} \\
\hline \multirow[t]{3}{*}{ Temperature Regime } & Temperature $\left({ }^{\circ} \mathrm{C}\right)$ & $\mathrm{a}$ & $21-25$ & $25-30$ & $30-35$ & $>35$ \\
\hline & & $\mathrm{b}$ & $21-25$ & $25-30$ & $30-35$ & $>35$ \\
\hline & & $\mathrm{c}$ & $21-25$ & $25-30$ & $30-35$ & $>35$ \\
\hline \multirow[t]{3}{*}{ Water Availability } & Total rainfall (mm) & a & $\geq 2000$ & $1300-1299$ & $1000-1299$ & $<1000$ \\
\hline & & $\mathrm{b}$ & $\geq 2000$ & $1300-1299$ & $1000-1299$ & $<1000$ \\
\hline & & $\mathrm{c}$ & $\geq 2000$ & $1300-1299$ & $1000-1299$ & $<1000$ \\
\hline \multirow{15}{*}{$\begin{array}{l}\text { Fertility (f): Nutrient } \\
\text { Availability }\end{array}$} & Total N (g/kg) & $\mathrm{a}$ & $>0.6$ & $0.3-0.5$ & $0.1-0.2$ & $<0.1$ \\
\hline & & $\mathrm{b}$ & $>0.6$ & $0.3-0.5$ & $0.1-0.2$ & $<0.1$ \\
\hline & & $\mathrm{c}$ & $>0.6$ & $0.3-0.5$ & $0.1-0.2$ & $<0.1$ \\
\hline & Available (mg/kg) & $\mathrm{a}$ & $60-43$ & $6-42$ & $4-5$ & $<4$ \\
\hline & & $\mathrm{b}$ & $60-43$ & $6-42$ & $4-5$ & $<4$ \\
\hline & & $\mathrm{c}$ & $60-43$ & $6-42$ & $4-5$ & $<4$ \\
\hline & Exch. K. $(\mathrm{cmol} / \mathrm{kg})$ & a & $>0.05$ & $0.03-0.04$ & $0.01-0.02$ & $<0.01$ \\
\hline & & $\mathrm{b}$ & $>0.05$ & $0.03-0.04$ & $0.01-0.02$ & $<0.01$ \\
\hline & & $\mathrm{c}$ & $>0.05$ & $0.03-0.04$ & $0.01-0.02$ & $<0.01$ \\
\hline & Organic matter $(\mathrm{g} / \mathrm{kg})$ & $\mathrm{a}$ & $>12.6$ & $8-12.5$ & $4-7$ & $<4$ \\
\hline & & $\mathrm{b}$ & $>12.6$ & $8-12.5$ & $4-7$ & $<4$ \\
\hline & & $\mathrm{c}$ & $>12.6$ & $8-12.5$ & $4-7$ & $<4$ \\
\hline & Soil pH & $\mathrm{a}$ & $7.5-5.2$ & $5.2-4.1$ & $3.9-4.1$ & $<3.9$ \\
\hline & & $\mathrm{b}$ & $7.5-5.2$ & $5.2-4.1$ & $3.9-4.1$ & $<3.9$ \\
\hline & & $\mathrm{c}$ & $7.5-5.2$ & $5.2-4.1$ & $3.9-4.1$ & $<3.9$ \\
\hline \multirow[t]{3}{*}{ Nutrient Retention } & Base Saturation (\%) & $\mathrm{a}$ & $>60$ & $40-60$ & $20-39$ & $<20$ \\
\hline & & $\mathrm{b}$ & $>60$ & $40-60$ & $20-39$ & $<20$ \\
\hline & & $\mathrm{c}$ & $>60$ & $40-60$ & $20-39$ & $<20$ \\
\hline \multirow{3}{*}{$\begin{array}{l}\text { Soil Physical Charac- } \\
\text { teristics (S): }\end{array}$} & Top Soil Texture & $\mathrm{a}$ & $\mathrm{C}$ & CL & SL & $\mathrm{S}$ \\
\hline & & $\mathrm{b}$ & Any & Any & Any & Any \\
\hline & & $\mathrm{c}$ & $\mathrm{L}$ & SL & SCL & $\mathrm{C}$ \\
\hline \multirow[t]{3}{*}{ Water Retention } & Soil Depth (cm) & a & $>40$ & $31-40$ & $21-30$ & $<20$ \\
\hline & & $\mathrm{b}$ & $>40$ & $31-40$ & $21-30$ & $<20$ \\
\hline & & $\mathrm{c}$ & $>40$ & $31-40$ & $21-30$ & $<20$ \\
\hline \multirow[t]{3}{*}{ Rooting Condition } & Water Table $(\mathrm{cm})$ & a & $40-50$ & $51-60$ & $61-70$ & $<70$ \\
\hline & & $\mathrm{b}$ & Any & Any & Any & Any \\
\hline & & $\mathrm{c}$ & $>50$ & $50-45$ & $45-40$ & $<40$ \\
\hline \multirow[t]{3}{*}{ Wetness (w): } & Drainage & $\mathrm{a}$ & $\begin{array}{l}\text { Very poorly } \\
\text { drained }\end{array}$ & $\begin{array}{l}\text { Poorly } \\
\text { drained }\end{array}$ & $\begin{array}{l}\text { Imperfectly } \\
\text { drained }\end{array}$ & Well drained \\
\hline & & $\mathrm{b}$ & Any & Any & Any & Any \\
\hline & & $\mathrm{c}$ & Well drained & $\begin{array}{l}\text { Imperfectly } \\
\text { drained }\end{array}$ & $\begin{array}{l}\text { Poorly } \\
\text { drained }\end{array}$ & $\begin{array}{l}\text { Very poorly } \\
\text { drained }\end{array}$ \\
\hline \multirow[t]{3}{*}{ Topography (t): } & Slope (\%) & $\mathrm{a}$ & $0-2$ & $2-4$ & $4-6$ & $>6$ \\
\hline & & $\mathrm{b}$ & Any & Any & Any & Any \\
\hline & & $\mathrm{c}$ & $>6$ & $4-6$ & $2-4$ & $0-2$ \\
\hline
\end{tabular}

Source: Heckett, 1984; FAO, 1976; Sarem et al., 2000 and Chukwu et al., 2014.

Key: $\mathrm{a}=$ Dasheen type-Colocasia esculenta var. esculenta plucknett, $\mathrm{b}=$ Eddoe type-Colocasia esculenta var. antiquorum plucknett, $\mathrm{c}=$ Tania-Xanthosoma sagittifolium 
TABLE 5

Suitability Class Scores of the Study Area for three varieties of Cocoyam (Colocasia spp)

\begin{tabular}{|c|c|c|c|c|c|}
\hline Land Qualities & Cocoyam Variety & $\boldsymbol{F P}$ & IV & $G S$ & CR \\
\hline \\
\hline & $\mathrm{a}$ & 95 (S1) & $95(\mathrm{~S} 1)$ & 95 (S1) & $95(\mathrm{~S} 1)$ \\
\hline \multirow{2}{*}{ Annual Rainfall } & $\mathrm{b}$ & 95 (S1) & 95 (S1) & 95 (S1) & 95 (S1) \\
\hline & $\mathrm{c}$ & 95 (S1) & 95 (S1) & 95 (S1) & 95 (S1) \\
\hline \multirow[t]{2}{*}{ Average Temperature } & $\mathrm{a}$ & $85(\mathrm{~S} 2)$ & $85(\mathrm{~S} 2)$ & $85(\mathrm{~S} 2)$ & $85(\mathrm{~S} 2)$ \\
\hline & $\mathrm{b}$ & 85 (S2) & $85(\mathrm{~S} 2)$ & $85(\mathrm{~S} 2)$ & 85 (S2) \\
\hline Wetness (w): & $\mathrm{c}$ & 85 (S2) & 85 (S2) & 85 (S2) & 85 (S2) \\
\hline \multirow[t]{3}{*}{ Drainage } & a & 95 (S1) & 95 (S1) & 40 (N1) & 40 (N1) \\
\hline & b & 95 (S1) & 95 (S1) & 95 (S1) & 95 (S1) \\
\hline & $\mathrm{c}$ & 40 (N1) & $60(\mathrm{~S} 3)$ & 85 (S2) & 95 (S1) \\
\hline \multirow[t]{3}{*}{ Topography (t): slope } & a & 95 (S1) & 85 (S2) & $60(\mathrm{~S} 3)$ & 40 (N1) \\
\hline & b & 85 (S2) & $85(\mathrm{~S} 2)$ & $85(\mathrm{~S} 2)$ & 95 (S1) \\
\hline & $\mathrm{c}$ & 40 (N1) & $60(\mathrm{~S} 3)$ & 85 (S2) & 95 (S1) \\
\hline \multirow{3}{*}{$\begin{array}{l}\text { Soil Characteristics (c): Soil Texture/ } \\
\text { Structure }\end{array}$} & $\mathrm{a}$ & $85(\mathrm{~S} 2)$ & 85 (S2) & $60(\mathrm{~S} 3)$ & $60(\mathrm{~S} 3)$ \\
\hline & $\mathrm{b}$ & 95 (S1) & $95(\mathrm{~S} 1)$ & $95(\mathrm{~S} 1)$ & $95(\mathrm{~S} 1)$ \\
\hline & $\mathrm{c}$ & 60 (S3) & 60 (S3) & 85 (S2) & 85 (S2) \\
\hline \multirow[t]{3}{*}{ Soil Depth } & $\mathrm{a}$ & 95 (S1) & 95 (S1) & 95 (S1) & 95 (S1) \\
\hline & b & 95 (S1) & 95 (S1) & 95 (S1) & 95 (S1) \\
\hline & $\mathrm{c}$ & 95 (S1) & 95 (S1) & 95 (S1) & 95 (S1) \\
\hline \multirow[t]{3}{*}{ Water Table } & a & 95 (S1) & 95 (S1) & 40 (N1) & 40 (N1) \\
\hline & $\mathrm{b}$ & 95 (S1) & 95 (S1) & 95 (S1) & 95 (S1) \\
\hline & $\mathrm{c}$ & 40 (N1) & 40 (N1) & 95 (S1) & 95 (S1) \\
\hline \multirow[t]{3}{*}{$\mathrm{pH}$} & a & 95 (S1) & 95 (S1) & 85 (S2) & 85 (S2) \\
\hline & $\mathrm{b}$ & 95 (S1) & 95 (S1) & 85 (S2) & 85 (S2) \\
\hline & $\mathrm{c}$ & 95 (S1) & 95 (S1) & 85 (S2) & $85(\mathrm{~S} 2)$ \\
\hline \multirow[t]{3}{*}{ Total Nitrogen } & a & 95 (S1) & 95 (S1) & $85(\mathrm{~S} 2)$ & 85 (S2) \\
\hline & $\mathrm{b}$ & 95 (S1) & 95 (S1) & 85 (S2) & 85 (S2) \\
\hline & $\mathrm{c}$ & 95 (S1) & 95 (S1) & $85(\mathrm{~S} 2)$ & 85 (S2) \\
\hline \multirow[t]{3}{*}{ Org. Carbon } & a & 95 (S1) & 95 (S1) & 85 (S2) & 85 (S2) \\
\hline & b & 95 (S1) & 95 (S1) & 85 (S2) & 85 (S2) \\
\hline & $\mathrm{c}$ & 95 (S1) & 95 (S1) & 85 (S2) & 85 (S2) \\
\hline \multirow[t]{3}{*}{ Avail. P. } & $\mathrm{a}$ & 85 (S2) & $85(\mathrm{~S} 2)$ & $60(\mathrm{~S} 3)$ & $60(\mathrm{~S} 3)$ \\
\hline & $\mathrm{b}$ & 85 (S2) & $85(\mathrm{~S} 2)$ & 60 (S3) & $60(\mathrm{~S} 3)$ \\
\hline & $\mathrm{c}$ & 85 (S2) & 85 (S2) & 60 (S3) & 60 (S3) \\
\hline \multirow[t]{3}{*}{ Exch. K } & $\mathrm{a}$ & 95 (S1) & 95 (S1) & 95 (S1) & 95 (S1) \\
\hline & b & 95 (S1) & 95 (S1) & 95 (S1) & 95 (S1) \\
\hline & $\mathrm{c}$ & 95 (S1) & 95 (S1) & 95 (S1) & 95 (S1) \\
\hline \multirow[t]{3}{*}{ Base Saturation } & $\mathrm{a}$ & 95 (S1) & 95 (S1) & 95 (S1) & 85 (S2) \\
\hline & b & 95 (S1) & 95 (S1) & 95 (S1) & 85 (S2) \\
\hline & $\mathrm{c}$ & 95 (S1) & 95 (S1) & 95 (S1) & 85 (S2) \\
\hline \multirow[t]{2}{*}{ Aggregate Suitability by Limitation } & a & S2 & S2 & N1 & N1 \\
\hline & $\mathrm{b}$ & S2 & $\mathrm{S} 2$ & S3 & S3 \\
\hline \multirow{3}{*}{$\begin{array}{l}\text { Productivity Index by Square Root } \\
\text { Method }\end{array}$} & $\mathrm{c}$ & N1 & N1 & S3 & S3 \\
\hline & a & 55.9 & 52.8 & 7.7 & 5.9 \\
\hline & $\mathrm{b}$ & 55.9 & 52.9 & 33.4 & 31.6 \\
\hline \multirow{4}{*}{ Rating } & $\mathrm{c}$ & 8.8 & 13.2 & 29.9 & 31.6 \\
\hline & a & $\mathrm{S} 2$ & S3 & N1 & N2 \\
\hline & b & S2 & $\mathrm{S} 2$ & S3 & S3 \\
\hline & c & N1 & N1 & S3 & S3 \\
\hline
\end{tabular}

Key: $\mathrm{a}=$ Dasheen type-Colocasia esculenta var. esculenta plucknett, $\mathrm{b}=$ Eddoe type-Colocasia esculenta var. antiquorum plucknett, $\mathrm{c}=$ Tania-Xanthosoma sagittifolium

$\mathrm{FP}=$ Flood plains, $\mathrm{IV}=$ Inland Valleys, $\mathrm{GS}=$ Gentle slope, $\mathrm{CR}=$ Crest 


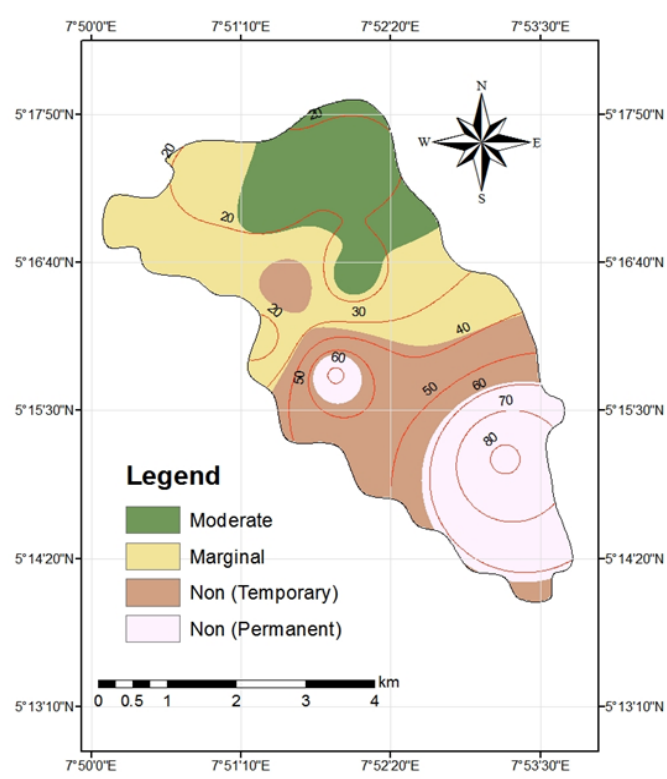

Fig. 2: Suitability Map of Study Area for Dasheen Type Taro (Colocasia esculenta var. esculenta plucknett) NCE 006

\section{Suitability Evaluation for Eddoe Type Taro (Colocasia esculenta var. Antiquorum plucknett) Nce 001}

The study indicated that climatic elements of rainfall and temperature are ideal for Eddoe Type taro cultivation in the study area and scored $95 \%(\mathrm{~S} 1)$ and $85 \%(\mathrm{~S} 2)$ respectively. Drainage and slope were rated moderately to highly suitable (85-95\%) for Eddoe Type Taro cultivation since these cocoyam varieties thrive on any terrain type and moisture condition (Chukwu et al., 2014). All the chemical soil characteristics except available phosphorous were rated moderately to highly suitable (85-
95\%) for all the soil units, (Table 5). Available phosphorus was moderately suitable (S2) in the flood plains and inland valleys and marginally suitable (S3) at the gentle slope and crest landforms.

Aggregate suitability evaluation by the simple (least) limitation method reveals that the soils of flood plains and inland valleys were moderately suitable (S2) while the soils on gentle slope and crest landforms were marginally suitable (S3) for Eddoe Type Taro cultivation in the study area. The square root parametric method equally indicated the same suitability ratings with the limitation method (Table 5). The result is presented in Figure 3.

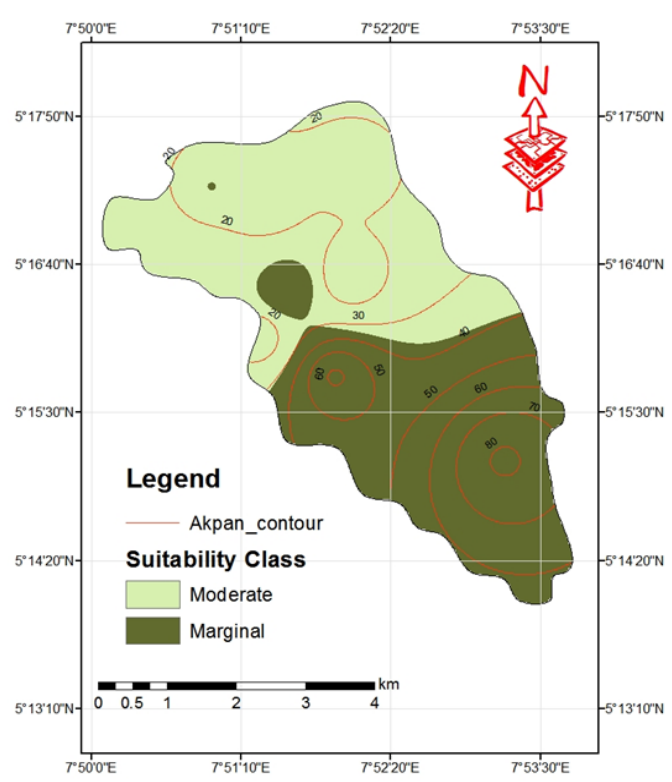

Fig. 3: Suitability Map of the Study Area for Eddoe Type Taro (Colocasia esculenta var. antiquorum pluckknett) NCE 001 
Suitability Evaluation for Tania (Xanthosoma sagittifolium) NXS 001

The climatic elements (rainfall and temperature) in the study area were scored $95 \%$ (S1) and $85 \%$ (S2) respectively for all landform types studied (Table 5). The flood plains were scored 40 (N1) for drainage and slope, implying that the flood plains are not suitable for Tania cultivation which requires well-drained soil conditions (Gooding, 1987). However, the soils of inland valleys were rated marginally suitable (S3) for Tania cultivation in terms of drainage and slope conditions. The gentle slopes and crest landforms had moderately to highly suitable (S1-S2) drainage and slope conditions for Tania cultivation. The structure/texture of the soils of flood plains and inland valleys which indicated the existence of heavy clayey soils were rated marginally suitable (S3) since heavy clayey soils according to Udealor et al. (1996) inhibits or restricts corm enlargement of Xanthosoma spp. On the contrary, the soils of gentle slopes and crest landforms possessing light soils were rated moderately suitable (S2) in terms of soil physical characteristics (structure/texture) for Tania cultivation. Soil depth was rated highly suitable (S1) in all landform types examined for Tania cultivation, (Table 5). The flood plains and inland valleys with high water tables were rated not suitable (N1) whereas the gentle slope and crest scored $95 \%$ and rated highly suitable (S1) for Tania cultivation in the study area. Sarem et al. (2008) reported that Tania cocoyam requires well-drained soils having water tables $>50 \mathrm{~cm}$ for optimal yields. All the soils chemical characteristics except available phosphorus were rated moderately to highly suitable $(85-95 \%)$ for Tania cultivation in all the landform types studied (Table 5). Available phosphorus was rated moderate $(85 \%)$ in the flood plains and inland valleys but marginal $(60 \%)$ for soils on gentle slopes and crest landforms.

Aggregate suitability by simple limitation method indicated that the soils of the flood plains and inland valleys were unsuitable (N1) on account of poor drainage and slope for Tania cultivation. The soils of gentle slopes and crest landforms were rated marginally suitable (S3) for Tania cultivation on grounds of low available phosphorus. The results of the square root method were similar to those obtained using the simple limitation method (Figure 4).

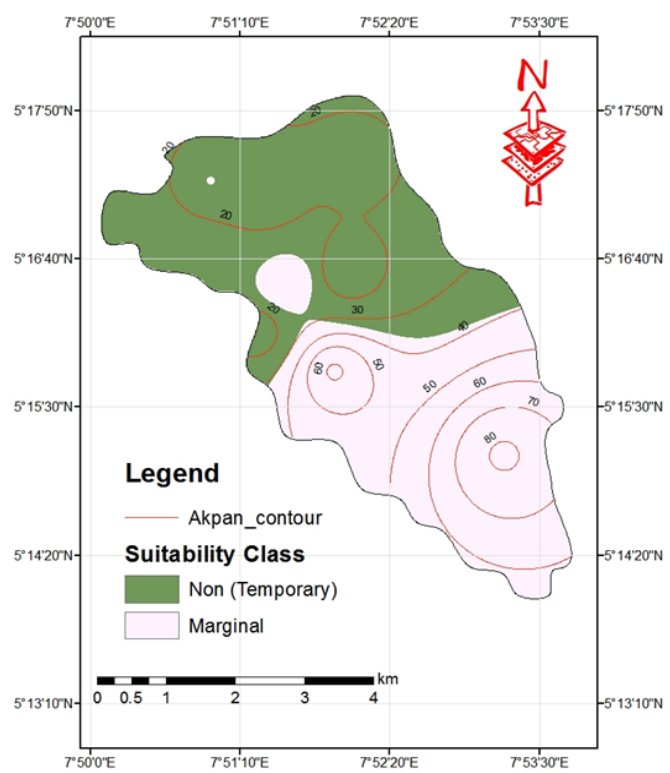

Fig. 4: Suitability Map of the Study Area for Tania (Xanthosoma sagittifolium) NXS 001 


\section{Classification of Soils in the Study Area}

The soils in the study area were classified according to the USDA soil taxonomy (Soil Survey Staff, 2014). The soils of flood plains had high base saturation, histic epipedons and cambic sub-soils. The flood plains soils were thus placed under the Inceptisol soil order. Their aquic soil moisture regime placed them as Aquepts at the sub-order level. At the great group level, there were classified Humaquepts due to their high organic carbon content. Their possession of histic epipedons qualifies to place them as Histic Humaquets at the great group level.

The inland valley soils were characterized by high base saturation greater than $50 \% \mathrm{NH}_{4} \mathrm{OA}_{\mathrm{C}}$ method, mollic epipedon and cambic sub-surface diagnostic horizons. These properties qualify the placement of the inland valley soils under the inceptisol soil order. Their aquic soil moisture regime placed them as Aquepts at the sub-order level. At the great group level, these soils were classified Epiaquepts due to episaturation (prolonged waterlogging) of this soil unit. The existence of numerous cracks wider than $5 \mathrm{~mm}$ within 120 $\mathrm{cm}$ of soil depth, that are deeper than $30 \mathrm{~cm}$ for some part of the year, qualify placing the inland valley soils as Vertic Epiaquepts at the sub-group level.

The soil of gentle slopes had base saturation less than $35 \%$ and possed Kandic and argillic (Bt) subsurface diagnostic horizons with plinthites, hence there were placed under the Ultisol soil order (Soil Survey Staff, 2014). Their Udic moisture regime qualifies as Udults at the sub-order level at the great group level, there were classified Kandiudults due to regular decrease in Organic Carbon with increasing soil depth. The occurrence of sub-soils plinthites qualifies them as Plinthic Kandiudults at the sub-group level.
The soils of the crest had medium to high base saturation greater than $35 \%$ and possessed Kandic and argillic (Bt) sub-soils. This placed the soils of this unit under the Alfisol soil order and as Udalfs at the suborder level. These soils were further classified Kandiudalfs at the great group level and as Arenic Kandiudalfs at the sub-group level due to their coarse-textured nature.

\section{Conclusion}

Most soils under agricultural land use are at great risk of misuse and subsequent degradation due to increasing demand and population pressure. This essentially hinders sustained national development. Consequently, for the potentials of agricultural land to be maximized for the production of food and fibre, there is a need to have an understanding and a balanced view of the most suitable options the land can be profitably utilized.

This study characterized and evaluated the flood plains and inland valley soils as moderately suitable, and the gentle slopes and crest as not suitable for Dasheen Taro. The flood plains and inland valleys were also evaluated moderately suitable whereas gentle slopes and crest were marginally suitable for Eddoe Taro cultivation. The soils of flood plains and inland valleys were evaluated unsuitable while the gentle slopes and crests landforms were rated marginally suitable for Tania cultivation in their present state.

Soil characterization and evaluation guarantee the sustained productive capacity of soils. However, it must be noted that over time, the continuous use of a previously evaluated soil for an ideal utilization decline. Consequently, the soils in Ikot Esidem, Ibiomo Ibom L.G.A of Akwa Ibom would require continuous periodic evaluation and management for sustainable 
production of cocoyam. Land suitability evaluation should be a basis for site selection to expand cocoyam production in the study area.

\section{Recommendations}

Based on the soil information obtained in this study, the following soil management approaches are recommended for soils in the study area. The flood plains sand inland valley soils possessing wetness as its major limitation can be improved for the production of cocoyam through efficient water table control and management. This measure would include impoundment of water to sustain the production of Dasheen and Eddoe type taro or an efficient drainage mechanism to enhance the production of Tania. The application of organic (poultry droppings, pig waste, compost, etc) and inorganic manures (NPK 15:15:15, single super phosphate, etc.) are recommended for soils on gentle slopes and crest landforms as these would add adequate nutrients to the soil thereby boosting the yield of cocoyam in the study area.

Application of organic manure and making of raised (high) mounds and ridges in soils of flood plains and inland valleys would help lighten heavy (clay) soils and improved drainage. This will favour the cultivation of Tania in the wetland soils of the study area. Agronomic measures such as the establishment of vetiver grass hedges, construction of ridges across the slope terracing and zero tillage would help ameliorate erosion hazard in the highly erodible soils of the crest and gentle slope landforms. The practice of leguminous intercropping could be used to beef up the nutrient status of soils in the study area. The application of lime-based on periodic soil tests is also recommended to enhance the availability of essential nutrients to crops, especially cocoyam in the study area.

\section{REFERENCES}

Abate, N.A., Kibebew, K., Heluf, G. \& Abayneh, E. (2014) Characterizaiton and Classification of Soils along the Toposequence at the Wadla Delanta Massif, North Central Highlands of Ethiopia. Journal of Ecology and the Natural Environment 6 (9), 304 - 320.

Adejumo, I.O. \& Bamidele, O. (2012) Cost Implication of differently processed wild Cocoyam (Colocasia esculenta) as Feed Ingredient for Broiler Finishers. Research Journal for Science Information Technology 1, 7 - 10.

Afu, S.M., Asadu, C.L.A. \& Effiom, D.O. (2016) Comparative Evaluation of the Contributions of Clay, Silt and Organic Matter to Cation Exchange Capacity of Soils under Common Landuse in Southeastern Nigeria. Nigerian Journal of Soil and Environmental Research 14, $114-124$.

Ahukaemere, C.M., Ndukwu, B.N., Ihem, E.E. \& Onwuso, G.I. (2016) Profile Characteristics of Selected Rice-producing Soils of Abia State in Southeastern Nigeria. Nigerian Journal of Soil Science 26, 146 - 153.

Akamigbo, F.O.R., Ezedinma, F.O.C. \& Igwe, C.A. (2002) Properties and Classification of some Fadama Soils of Bauchi State, Nigeria. Proceedings of the $27^{\text {th }}$ Annual Conference of the Soil Science Society of Nigeria. $45-51$.

Aluko, A.P., Adebiyi, O.V., Oshiokhue, C.E. \& Adejoh, O.P. (2016) Forms of Phosphorus in three Ecological Zones of Nigeria. Proceedings of the $40^{\text {th }}$ Annual Conference of the Soil Science Society of Nigeria held at Calabar. $195-200$.

AOAC (1990) Association of Official Analytical Chemist, Methods of Analysis ( $12^{\text {th }}$ edition). Washington D. C.

Asadu, C.L.A., Akamigbo, F.O.R., Ezumah, H.C. \& Nweke, F.I. (1990) The Characteristics of Selected Yam Growing Soils in South East- 
ern Nigeria: Physical and Morphological Properties. Nigerian Agricultural Journal 24, $55-69$.

Best, M.G. (1982) Igneous and Metamorphic Petrology. W.H. Freeman and Company, New York. p. 484.

Brady, N.C. \& Weil, R.R. (2008) The Nature and Properties of Soils, $14^{\text {th }}$ Edition, Prentice-Hall, Upper Saddle River, NJ. p. 564.

Bremner, J.M. (1996) Nitrogen Total. In: Sparks, D.L. (Ed). Methods of Soil Analysis, Part 3, Chemical Methods, SSSA Book Series 5, Soil Science Society of America, Madison, Wisconsin. $1085-1122$.

\section{Chukwu, G.O., Nwosu, P.O., \& Onyekwere, I.O} (2014) Suitability Evaluation of Land Resources Zones of Nigeria for Cocoyam Production. United Open Soil Science Journal 1 (1), $1-8$. Available online at http://arepub. com/Journals.php

Essoka, A.N. \& Esu, I.E. (2003) Physical Properties of Inland Valley Soils of Central Cross River State, Nigeria. Global Journal Agriculture Research 2 (1), 37 - 42.

FAO (2006) Guideline for Soil Description (4 $4^{\text {th }}$ Ed). Food and Agriculture Organization of United Nations, FAO, Rome, Italy. p. 97.

FAO (2007) Land Evaluation: Towards a Revised Framework. Land and Water Discussion. Paper-6, FAO, Rome, Italy. p. 107.

FMANR (1990) Literature Review on Soil Fertility Investigations in Nigeria (in five volumes). Federal Ministry of Agriculture and Natural Resources, Abuja. p. 281.

Gee, G. W. \& Or, D. (2002) Particle Size Determination In:Method of Soil Analysis, Part4. Physical Methods. Dane, J. H. and Troops. G.C. (Eds). Soil Science Society of American Book Series No. 5 and American Society of Agronomy, Madison Wisconsin, 201 - 228.
Gooding, E.G.B. (1987) Tannia (Xanthosama spp) and Taro (Colocasia esculenta) In: Root Crops, 2nd edition. Tropical Development and Research Institute, London. $200-251$.

Halder, J. (2013) Land Suitability Assessment for Crop Cultivation Using Remote Sensing and GIS. Journal of Geography and Geology $\mathbf{5}$ (3), $65-74$.

Idoga, S., Abagyeh, S.O. \& Agber, P.I. (2005) Characteristics and Classification of Crop Products in Potentials of Soils of the Aliade Plain, Benue State, Nigeria. Nigeria Journal of Soil Science 15, $101-110$.

Khiddir, S.M. (1986) A statistical Approach in the Use of Parametric Systems Applied to the FAO Framework for Land Evaluation. [Ph.D. Thesis.] State University Ghent. p. 88.

Kuo, S. (1996) Determination of Phosphorus. In: Sparks, D. L. (Ed). Methods of Soil Analysis. Part 3. Chemical Methods. Book Series 5. American Society of Agronomy and Soil Science Society of America, Madison, Wisconsin, $869-892$.

McKenzie, R. (1992) Micronutrients Requirement of Crops, Agdex 531 - 541. Alberta Agriculture, Food and Rural Development.

Mohammad, G.H. (2011) Land Suitability Evaluation for some Selected Landuse Types in the Institute for Agricultural Research Farm, Zaria, Nigeria. An Unpublished M.Sc. Thesis, Department of Soil Science, Ahmadu Bello University, Zaria.

Nelson, D.W. \& Sommers, L.E. (1996) Total Carbon:Organic Carbon and Organic Matter. In: Sparks, D. L. (Ed.). Methods of Soil Analysis. Part 3. Chemical Methods. Book Series 5. American Society of Agronomy and Soil Science Society of America, Madison, Wisconsin. $961-1010$.

Nsor, M.E \& Akamigbo F.O.R. (2009) Characterization, Classification and Landuse Manage- 
ment of Flood Plain Soils of Central Cross River State, Nigeria. Global Journal of Agricultural Sciences 8 (1), 39 - 46.

Nsor, M.E. \& Adesemuyi, E.A. (2016) Characterization of Soils along a Toposequence in Ishiagu, Eastern Nigeria and its Relation to Potential Agricultural Landuse. Nigerian Journal of Soil Science 26,78 - 86.

Nsor, M.E., Otu, E.J., Okeafor, M.O. \& Lifu, M.I. (2014) Physico-chemical Evaluation and Site Suitability Assessment of Selected Flood Plain Soils along River Cross for Arable Cropping. Journal of the Science of Agriculture, Food Technology and the Environment 13, 19-31.

Odunze, A.E. (2006) Soil Properties and Management Strategies for some Sub-Humid Altisols of Savanna Zone in Kaduna State, Nigeria. Samaru Journal of Agricultural Research 22, $3-14$.

Okonkwo, E. I. \& Nsor, M. E. (2015) Land Suitability Evaluation of Wetland Soils of Adani, Enugu State, Nigeria for Swamp Rice Cultivation. Journal of Sustainable Agricultural and the Environment 16 (1), 121 - 138.

Olayiwola, F.F., Abdul-Rasaq, A., Onabanjo, O., Sanni, A. \& Afolabi, W. (2013) Chemical Mineral Composition, and Sensory Acceptability of Cocoyam-based Recipes Enriched with Cowpea Flour. Food Science Nutrition 13, $228-234$.

Riquier, J., Bromao, D.L. \& Cornet, J.P. (1970) A New System Soil Appraisal in terms of Actual and Potential Productivity, FAO,Rome. p. 44.
Sarem, A.K., Palapala, V, Talwana, H., Nandi, J.M.O., Ndabikunze, B. \& Korir, M.K. (2008) Socioeconomic Constraints to Sustainable Cocoyam Production in the Lake Victoria Crescent. African Journal of Environmental Science and Technology 2 (10), $305-308$.

Sharu, M., Yakubu, A.I. \& Tsafe, S.N.A. (2013) Characterization and Classification of Soils on any Agricultural Landscape in Dingyadi District, Sokoto State, Nigeria. Journal of Basic and Applied Sciences 21 (2), 137 147.

Soil Survey Staff (2014) keys to Soil Taxonomy (12 Edition), USDA National Resources Conservation Service, Washington, DC. p. 372.

Sys, C., Van Ranst, E., Debaveye, J. \& Beernaert, F. (1993) Land evaluation, Part 3. Crop Requirements. Agricultural Publications 7. General Administration. Developnment for. Cooperation. Brussels. p. 191.

Udealor A., Nwadukwe, P.O., Okoronya, J.A. \& Plucknet D.C (1996) Management of Crop Xanthosoma, Alocasia, Crystosperma and Amorpholosphallus.In: Tropical Root Crops Tomorrow (Eds). Proceedings of International Symposium on Tropical Root Crops. Hawaii. 127 - 135.

Usoro, E.J. \& Akpan, P.A. (2010) Akwa Ibom State: A Geography in perspective. Immaculate publication, Enugu. $23-51$

Van Wambeke, A. (1962) Criteria for Classifying Tropical Soils by Age. Journal of Soil Science 13, $124-132$.

Watanabe, K.Z. (2002) Challenges in Biotechnology for Abiotic Stress Tolerance on Root and Tubers. JIRCAS Working Reports. $75-83$. 